Brit. F. vener. Dis. (1969), 45, 151.

\title{
SENSITIVITY TO PENICILLIN OF Neisseria gonorrhoeae
}

\section{RELATIONSHIP TO THE RESULTS OF TREATMENT}

\author{
BY \\ D. A. LEIGH†, J. LE FRANC, AND A. R. TURNBULL, F.I.M.L.T. \\ From the Department of Microbiology, The Wright-Fleming Institute, \\ St. Mary's Hospital Medical School, London
}

Despite the reports of many workers in Great Britain (King, 1958; Willcox, 1958; Curtis and Wilkinson, 1958; Willcox, 1964) that the resistance of Neisseria gonorrhoeae to penicillin, as judged by the treatment failure rate, is increasing, there is little evidence in the overall results of these and other studies to show a progressive decrease in sensitivity after 1957 (M.R.C. Working Party, 1961; British Medical fournal, 1968). Changes in the incidence of less sensitive strains undoubtedly occur at different times in different neighbourhoods and this can sometimes be related to a change in the antibiotic dose regime (Letchner and Nicol, 1961; Morton and Higson, 1966) or to the introduction of patients with infections contracted overseas (Warren, 1968). There is also a considerable lack of standardization of laboratory methods (Reyn, Bentzon, and Ericsson, 1963) and this makes comparison of results difficult. It is very important to carry out frequent epidemiological surveys, as it is only by this means that a permanent increase in the numbers of less sensitive strains isolated in any area can be accurately detected.

This paper reports the penicillin sensitivities of strains of $N$. gonorrhoeae isolated at St. Mary's Hospital, London, during a 12-week period in 1968, and correlates the sensitivity of the infecting strain with the results of treatment.

\section{Patients and Methods}

The study was limited to cases in men with a purulent urethral discharge who attended the Special Clinic during the morning session, either for the first time or for a re-attendance with a new infection at least one month after the last attendance.

Gram-stained films of the urethral discharge were examined in the clinic and treatment for gonorrhoea was given when Gram-negative intracellular diplococci were seen.

^Received for publication, October 21, 1968.

tPresent address: Consultant Bacteriologist, Pathology Department, Wycombe General Hospital, High Wycombe, Bucks.
A swab was taken of the discharge and placed in Stuart's transport medium. This was stored in a warm position and at the end of the clinic all the specimens were collected by the laboratory staff and examined immediately.

In the laboratory the swab was plated on to warm serum chocolate agar plates which were then incubated for 48 hours. Typical colonies of $N$. gonorrhoeae were identified by Gram-stained films and the oxidase reaction; atypical colonies were further identified by biochemical tests.

The determination of the minimum inhibitory concentration (m.i.c.) of penicillin was carried out using a plate assay method. Serum chocolate agar plates were prepared and benzylpenicillin was added to give a final concentration of $0.5,0.2,0.1,0.05$, and 0.025 units per $\mathrm{ml}$. A colony of each strain of $N$. gonorrhoeae was emulsified in $0.2 \mathrm{ml}$. peptone water to give a just cloudy solution and a loopful of this suspension was placed on each of the five penicillin plates and on a control plate without penicillin. The area of inoculation on each plate was approximately $1 \mathrm{sq} . \mathrm{cm}$. The Oxford Staphylococcus was used as a control organism ${ }^{\star}$ and this grew on all plates up to and including that with $0 \cdot 1$ unit penicillin per $\mathrm{ml}$. The plates were incubated and read at 48 hours. The m.i.c. was the concentration of penicillin in the first plate on which the organism failed to grow.

The antibiotic sensitivity of the first 63 strains of $N$. gonorrhoeae was also determined using the impregnated disc technique with discs containing $1 \mu \mathrm{g}$. (1.3 units).

The results of treatment were assessed from the clinic notes. Only the patients followed-up for 1 to 2 weeks were included in the treatment study, and known cases of re-infection were excluded.

^At the end of the study the three WHO International Reference strains of Neisseria gonorrhoeae were obtained from Dr A. Reyn, of the State Serum Institute, Copenhagen, and the penicillin sensitivities were determined using our method. The results were: for Strain III0.05 , Strain V-0.5, and Strain VII-less than 0.025 units per $\mathrm{ml}$. These findings compare favourably with those reported by the Reference Laboratories of the WHO. 


\section{Results}

Between April and July, 1968, specimens of purulent urethral discharge were examined from 482 men attending the morning session of the clinic, and $N$. gonorrhoeae was isolated on culture from 201 (42 per cent.); 37 men were excluded from the treatment study, twelve ( 6 per cent.) because the strain of $N$. gonorrhoeae failed to grow on subculture and the result of the sensitivity was not known and 25 ( 12 per cent.) because they failed to attend for follow-up. Of the 164 men in the treatment study, 100 were attending the clinic for the first time and 64 were re-attending with a new infection.

The distribution of m.i.c. of benzylpenicillin for the 189 strains examined is shown in Table $I$; 60 per cent. of strains were sensitive to penicillin concentrations of less than 0.1 units per ml., and over 90 per cent. were inhibited by $0 \cdot 2$ units per $\mathrm{ml}$. or less. There was no significant difference in distribution between the strains isolated from first attenders, re-attenders, or men who failed to attend for follow-up after treatment.

Of the 164 men treated, 138 received penicillin, usually in a single dose of 1.2 mega units aqueous procaine penicillin, but a few were given $2 \cdot 4$ mega units, 87 of these men were first attenders and 51 were re-attenders. The cure rate was the same (86 per cent.) in both groups.

The treatment failure rate was found to be directly related to the sensitivity of the infecting strain (Table II) and rose from 6.3 per cent. when the m.i.c. was 0.025 units per $\mathrm{ml}$. or less to 55 per cent. when it was over 0.5 units per $\mathrm{ml}$.

26 men received treatment with another antibiotic, usually tetracycline, because of penicillin hypersensitivity. The cure rate in first attenders was 92 per cent. and in re-attenders 69 per cent., but in view of the small numbers of men treated this difference is not significant.
TABLE II

RELATIONSHIP OF m.i.c. OF INFECTING STRAIN OF N. GONORRHOEAE TO FAILURE OF TREATMENT

\begin{tabular}{l|c|c|c}
\hline \multirow{2}{*}{ m.i.c. (units/ml.) } & \multirow{2}{*}{$\begin{array}{c}\text { No. of } \\
\text { Cases }\end{array}$} & \multicolumn{2}{|c}{ Failures } \\
& & No. & Per cent. \\
\hline 0.025 or less & 63 & 4 & 6.3 \\
0.05 & 21 & 1 & 4.8 \\
0.1 & 26 & 4 & 15 \\
0.2 & 15 & 3 & 20 \\
0.5 & 4 & 2 & 50 \\
Over 0.5 & 9 & 5 & 55 \\
\hline
\end{tabular}

The relationship between the m.i.c. of penicillin and the zone size obtained by impregnated disc testing was poor. When the strain was sensitive to 0.2 units per ml. or less, almost 60 per cent. of the disc tests would have been recorded as resistant (zone size excluding the diameter of the disc less than $12 \mathrm{~mm}$.). Similarly, 17 per cent. of strains sensitive only to 0.5 units per $\mathrm{ml}$. or more would have been recorded as sensitive by the disc test.

\section{Discussion}

The results of this small study in 1968 showed that over 90 per cent. of "street" strains of $N$. gonorrhoeae isolated at St. Mary's Hospital were sensitive to 0.2 units per $\mathrm{ml}$. or less of benzylpenicillin, and these findings are similar to those reported from the same clinic in 1958 (M.R.C. Working Party, 1961). There was no difference in the distribution of sensitivities between strains isolated from cases in first attenders and those from cases of re-infection.

Treatment with aqueous procaine penicillin was successful in 86 per cent. of cases in both groups.

When failure of penicillin treatment occurred, it was directly related to the sensitivity of the infecting organism. This observation has been noted in part by many workers (Curtis and Wilkinson, 1958; Cradock-Watson, Shooter, and Nicol, 1958), but it is interesting to find in this study that four (45 per cent.) of the nine men with strains sensitive only

TABLE I

MINIMAL INHIBITORY CONCENTRATION (m.i.c.) OF BENZYLPENICILLIN FOR 189 STRAINS OF NEISSERIA GONORRHOEAE ISOLATED AT ST. MARY'S HOSPITAL

\begin{tabular}{|c|c|c|c|c|c|c|c|c|}
\hline \multirow{2}{*}{ m.i.c. (units/ml.) } & \multicolumn{2}{|c|}{ First Attenders } & \multicolumn{2}{|c|}{ Re-attenders } & \multicolumn{2}{|c|}{ No Follow-up } & \multicolumn{2}{|c|}{ Total } \\
\hline & No. & Per cent. & No. & Per cent. & No. & Per cent. & No. & Per cent. \\
\hline $\begin{array}{l}0.025 \text { or less } \\
0.05 \\
0.1 \\
0.2 \\
0.5 \\
\text { Over } 0.5\end{array}$ & $\begin{array}{r}46 \\
17 \\
18 \\
9 \\
6 \\
4\end{array}$ & $\begin{array}{r}46 \\
17 \\
18 \\
9 \\
6 \\
4\end{array}$ & $\begin{array}{r}28 \\
8 \\
15 \\
6 \\
1 \\
6\end{array}$ & $\begin{array}{l}44 \\
12 \cdot 5 \\
23 \\
9 \\
1 \cdot 5 \\
9\end{array}$ & $\begin{array}{r}12 \\
2 \\
5 \\
5 \\
1 \\
-\end{array}$ & $\begin{array}{r}48 \\
8 \\
20 \\
20 \\
4\end{array}$ & $\begin{array}{r}86 \\
27 \\
38 \\
20 \\
8 \\
10\end{array}$ & $\begin{array}{r}46 \\
14 \\
20 \\
11 \\
4 \\
5\end{array}$ \\
\hline Total & 100 & & 64 & & 25 & & 189 & \\
\hline
\end{tabular}


to more than 0.5 units per $\mathrm{ml}$. nevertheless responded to penicillin treatment. Just as paradoxically, when the strain was highly sensitive $(0.025$ units per ml. or less), over 6 per cent. of cases failed to respond to treatment.

Data on the serum levels of penicillin achieved with the various penicillin compounds are scarce (Willcox, 1968); in many cases in which failure of treatment has occurred, the level may not have been adequate for complete eradication of the infection. Failure of penicillin treatment does not indicate the presence of any other underlying abnormality, as the cure rate using a different antibiotic is similar whether it is used for primary or secondary treatment. The serum concentration attained with any particular dose regime will undoubtedly vary not only from patient to patient but in an individual patient given repeated doses.

In considering strains of $N$. gonorrhoeae which fail to respond to penicillin treatment, the serum level may not be the only important factor controlling the eradication of infection. The relationship of serum levels of penicillin to tissue levels is still unknown, and Thayer, Perry, Magnuson, and Garson (1957) have shown that phagocytosed gonococci are more resistant to the action of antibiotics. The levels of antibiotic in the urine and especially in the prostatic fluid may be significant when a sensitive strain fails to respond to otherwise adequate treatment that more emphasis should be laid on the relationship of serum and tissue concentrations of penicillin to failure of treatment in order that satisfactory regimes of treatment can be introduced which will reduce the likelihood of the emergence of resistant strains.

Despite individual reports of decreased sensitivity of $N$. gonorrhoeae to penicillin, truly resistant strains which cannot be treated with penicillin have yet to be isolated in Britain.

\section{Summary}

The sensitivity to penicillin of 189 strains of $N$. gonorrhoeae, isolated from male cases at St. Mary's Hospital, London, was determined using a plate assay technique; over 90 per cent. of strains were found to be sensitive to 0.2 units per ml. or less. There was no substantial difference between the penicillin resistance of the strains isolated in 1968 and that of the strains isolated in 1958.
86 per cent. of cases of gonorrhoea responded to penicillin treatment (in most cases a single injection of 1.2 mega units aqueous procaine penicillin and in some an injection of 2.4 mega units). Treatment failure was found to be directly related to the sensitivity of the infecting strain.

We should like to thank Dr F. J. G. Jefferiss and Dr R. R. Willcox for permission to carry out this study on their patients and the staff of the Special Clinic, St. Mary's Hospital, for collecting the urethral specimens.

\section{REFERENCES}

British Medical fournal (1968). Leader, 3, 391.

Cradock-Watson, J. E., Shooter, R. A., and Nicol, C. S. (1958). Brit. med. F., 1, 1091.

Curtis, F. R., and Wilkinson, A. E. (1958). Brit. F. vener. Dis., 34, 70.

KING, A. J. (1958). Lancet, 1, 651.

LeTCHNER, E. H., and NiCOL, C. S. (1961). Brit. $\mathcal{F}$. vener. Dis., 37, 158.

Morton, R. S., and Higson, D. W. (1966). Ibid., 39, 175.

M.R.C. Working PARTY (1961). Lancet, 2, 226.

ReYN, A., Bentzon, M. W., and ERICsson, H. (1963). Acta path. microbiol. scand., 57, 235.

Thayer, J. D., Perry, M. I., Magnuson, H. J., an Garson, W. (1957). Antibiot. and Chemother., 7, 311.

WARREN, R. M. (1968). Brit. F. vener. Dis., 44, 80.

WillcoX, R. R. (1958). Bull. Wld Hlth Org., 19, 503. (1964). Brit. F. vener. Dis., 40, 118. (1968). Personal communication.

La relation entre la sensibilité de Neisseria gonorrhoeae à la pénicilline et les résultats du traitement

\section{RÉSUMÉ}

La sensibilité à la pénicilline de 189 souches de Neisseria gonorrhoeae, isolées de malades du St. Mary's Hospital à Londres, a été déterminée en employant une technique de culture sur plaque; plus de 90 pour cent des souches étaient sensibles à 0,2 unités par $\mathrm{ml}$. ou moins. Il n'y avait aucune différence entre la résistance à la pénicilline des souches isolées en 1968 et celle des souches isolées en 1958.

86 pour cent des cas de gonococcie ont répondu au traitment à la pénicilline (dans la plupart des cas une seule injection de 1,2 méga unités de procaine pénicilline aqueuse et dans d'autres une injection de 2,4 méga unités). L'échec au traitement a été vu comme étant en rélation directe avec la sensibilité de la souche infectante. 